\title{
Development and validation of HPLC-DAD method of determination piperidinium 2-((5-(furan-2-yl)-4-phenyl-4H-1,2,4-triazol-3-yl)thio)acetate in $1 \%$ solution
}

\author{
B. 0. Varynskyi, V. V. Parchenko, A. G. Kaplaushenko
}

Zaporizhzhia State Medical University, Ukraine

Purpose. The purpose of this research is to develop new, highly sensitive and selective method for determination of piperidinium 2-((5-(furan-2-yl)-4-phenyl-4H-1,2,4-triazol-3-yl)thio)acetate as an active pharmaceutical ingredient (API) in $1 \%$ injection solution based on high performance liquid chromatography with diode-array detection.

Materials and methods. LC System was Agilent 1260 Infinity (degasser, binary pump, autosampler, thermostatted column compartment, diode array detector). Single quadrupole mass spectrometer Agilent 6120 with ionization in electrospray (ESI). Open LAB CDS Software. Column was Zorbax SB-C18; $30 \mathrm{~mm} \times 4.6 \mathrm{~mm} ; 1.8 \mu \mathrm{m}$. Injection volume was $2 \mu \mathrm{L}$. Isocratic mode. The mobile phase was water/acetonitrile (70:30) with $0.1 \%$ methanoate acid. Standard samples were piperidinium 2-((5-(furan-2-yl)4-phenyl-4H-1,2,4-triazol-3-yl)thio)acetate, furan-2-carbohydrazide, 2-(furan-2-carbonyl)- $\mathrm{N}$-phenylhydrazine-1-carbothioamide, 5-(furan-2-yl)-4-phenyl-2,4-dihydro-3H-1,2,4-triazole-3-thione.

Results. The graphs of the capacity factor from the acetonitrile concentration dependence in the mobile phase for potential impurities and API on diode-array detector were constructed. Optimal chromatography separation conditions for impurities and API were proposed. The UV spectra of API and impurities were presented. The API peak purity by mass spectrometric detector was determined. Method of the quantitative determination of the API in $1 \%$ solution for injection was elaborated. Total sample preparation uncertainty was predicted. Method was validated according to European and Ukrainian Pharmacopeia. It was applied for real samples solutions for injection.

Conclusions. The chromatography separation conditions of impurities and piperidinium 2-((5-(furan-2-yl)-4-phenyl-4H-1,2,4triazol-3-yl)thio)acetate were studied. The method of determination of piperidinium 2-((5-(furan-2-yl)-4-phenyl-4H-1,2,4-triazol3 -yl)thio)acetate in $1 \%$ solution for injection was elaborated. The results of the method validation show that it is specific and meet the requirements of linearity, precision and accuracy.

\section{Розробка та валідація ВЕРХ-АМА методики визначення піперидиній 2-((5-(фуран-2-іл)-4-феніл-4H-1,2,4-тріазол-3-іл)тіо) ацетату в 1 \% розчині}

\section{Б. О. Варинський, В. В. Парченко, А. Г. Каплаушенко}

Мета роботи - розроблення нового, високочутливого та селективного способу визначення піперидиній 2-((5- (фуран-2іл) -4-феніл-4H-1,2,4-тріазол-3-іл)тіо) ацетату як активного фрармацевтичного інгредієнта (АФІ) в 1 \% розчині для ін'єкцій на основі високоефективної рідинної хроматограффії з діодно-матричною детекцією.

Матеріали та методи. Рідинно-хроматографічна система Agilent 1260 Infinity (дегазатор, бінарний насос, автоматичний дозатор, термостат колонки, діодно-матричний детектор). Одноквадрупольний мас-спектрометр Agilent 6120 з іонізацією електророзпиленням (ECI). Програмне забезпечення Open LAB CDS Software. Колонка Zorbax SB-C18; 30 мм × 4,6 мм; 1,8 мкм. Інжектувальний об'єм становив 2 мкл. Ізократичний режим. Рухома фаза вода/ацетонітрил (70:30) із 0,1 \% метанової кислоти. Стандартні зразки піперидиній 2-((5-(фуран-2-іл)-4-феніл-4Н-1,2,4-тріазол-3-іл)тіо) ацетат, фуран-2-карбогідразид, 2- (фуран-2-карбоніл)-N-фенілгідразину-1-карботіоамід, 5-(фуран-2-іл)-4-френіл-2,4-дигідро-3Н-1,2,4-тріазол-3-тіон.

Результати. Побудовані графіки залежності коефіцієнта ємності від концентрації ацетонітрилу в рухомій фазі для потенційних домішок та АФІ на діодно-матричному детекторі. Запропоновані оптимальні умови хроматографічного розділення для домішок та АФІ. Представлені УФ-спектри АФІ та домішок. Визначена чистота піка АФІ за допомогою мас-спектрометричного детектора. Розроблена методика кількісного визначення АФІ в 1 \% розчині для ін'єкцій. Спрогнозована загальна похибка підготовки зразка. Методика валідована згідно з Європейською та Державною Фармакопеєю України. Спосіб застосовується для реальних зразків розчинів для ін'єкцій.

Висновки. Вивчені умови хроматографрічного розділення домішок і піперидиній 2-((5-(фруран-2-іл)-4-френіл-4Н-1,2,4-триазол-3-іл)тіо) ацетату. Розроблений спосіб визначення піперидиній 2-((5-(фуран-2-іл)-4-феніл-4Н-1,2,4-триазол-3-іл)тіо) ацетату у вигляді 1 \% розчину для ін'єкцій. Результати валідації методу показують, що методика специфічна та відповідає вимогам лінійності, правильності та відтворюваності.

\section{Разработка и валидация ВЭЖХ-АМА методики определения пиперидиний 2-((5-(фуран-2-ил)-4-фенил-4Н-1,2,4-триазол-3-ил)тио) ацетата в 1 \% растворе}

\section{Б. А. Варинский, В. В. Парченко, А. Г. Каплаушенко}

Цель работы - разработка нового высокочувствительного и селективного способа определения пиперидиний 2-((5-(фуран-2-ил)-4-френил-4H-1,2,4-триазол-3-ил)тио) ацетата в качестве активного фрармацевтического ингредиента в $1 \%$ растворе для инъекций на основе высокоэффективной жидкостной хроматографии с диодно-матричной детекцией.

Ключевые слова: триазолы, жидкостная хроматография высокого давления, фармацевтическая продукция, ветеринарные препараты. 
Запорожский медицинский журнал. - 2017. -

T. 19, № 6(105). C. 827-832

Материалы и методы. Жидкостно-хроматографическая система Agilent 1260 Infinity (дегазатор, бинарный насос, автоматический дозатор, термостата колонки, диодно-матричный детектор). Одноквадрупольный масс-спектрометр Agilent 6120 с ионизацией электрораспылением (ЭСИ). Программное обеспечение Open LAB CDS Software. Колонка Zorbax SB-C18; 30 мм × 4,6 мм; 1,8 мкм. Инжектируемый объем составил 2 мкл. Изократический режим. Подвижная фраза вода/ацетонитрил (70:30) с 0,1 \% метановой кислоты. Стандартные образцы пиперидиний 2-((5-(фуран-2-ил)-4-фенил4H-1,2,4-триазол-3-ил)тио) ацетат, фуран-2-карбогидразид, 2-(фуран-2-карбонил)-N-френилгидразина-1-карботиоамид, 5-(фруран-2-ил)-4-фенил-2,4-дигидро-3Н-1,2,4-триазол-3-тион.

Результаты. Построены графики зависимости коэффициента емкости от концентрации ацетонитрила в подвижной фазе для потенциальных примесей и АФИ на диодно-матричном детекторе. Предложены оптимальные условия хроматографического разделения для примесей и АФИ. Представлены УФ-спектры АФИ и примесей. Определена чистота пика АФИ с помощью масс-спектрометрического детектора. Разработана методика количественного определения АФИ в 1 \% растворе для инъекций. Спрогнозирована общая погрешность пробоподготовки. Методика валидирована в соответствии с Европейской и Государственной Фармакопеей Украины. Способ применен на реальных образцах растворов для инъекций.

Выводы. Изучены условия хроматографического разделения примесей и пиперидиний 2-((5-(фуран-2-ил)-4-френил4H-1,2,4-триазол-3-ил)тио) ацетата. Разработан способ определения пиперидиний 2-((5- (фуран-2-ил)-4-фенил-4H1,2,4-триазол-3-ил) тио) ацетата в 1 \% растворе для инъекций. Результаты валидации методики показывают, что она специфична и соответствует требованиям линейности, правильности и воспроизводимости.

\section{Introduction}

Derivatives of 1,2,4-triazoles are widely used as active pharmaceutical ingredients (API) of the medical preparations. Piperidinium 2-((5-(furan-2-yl)-4-phenyl-4H-1,2,4-triazol-3-yl) thio)acetate is API of the veterinary drug "Tryfuzole". It has hepatoprotective, cardioprotective, antioxidant, imunomodulating, interferonogenic, anti-inflammatory, detoxifying and wound healing action.

Determination of API in the manufacture and storage of solution for injection is an important task of modern pharmaceutical analysis.

Qualitative and quantitative methods of piperidinium 2-((5-(furan-2-yl)-4-phenyl-4H-1,2,4-triazol-3-yl)thio)acetate determination in the $1 \%$ and $2.5 \%$ solutions have been developed earlier. Its ability to absorb light in the ultraviolet region of the spectrum was used for quantification of these compounds. Maximum absorption of aqueous solution was $280 \mathrm{~nm}$. Distilled water was used as a solvent. Spectrophotometric method has low sensitivity and low selectivity [1].

There is also a method of determining of piperidinium 2-((5-(furan-2-yl)-4-phenyl-4H-1,2,4-triazol-3-yl)thio)acetate in bulk drug. It is not selective, based on potentiometric titration of the compound with a solution of perchlorate acid. This method is also insensitive [2].

\section{The purpose}

The purpose of this research is to develop new, highly sensitive and selective method for determination of these compounds in $1 \%$ injection solution based on high performance liquid chromatography with diode-array detection.

\section{Materials and methods}

The HPLC device: Agilent 1260 Infinity (degasser, binary pump, autosampler, thermostatted column compartment, diode-array detector); single quadrupole mass spectrometer Agilent 6120 with ionization in electrospray (ESI), OpenLAB CDS Software. Column Zorbax SB-C18; 30 mm x 4.6 mm; $1.8 \mu \mathrm{m}$.

Reagents: acetonitrile «HPLC Super gradient» grade (Avantor performance materials inc, Poland), methanoate acid (pure, AppliChem GmbH, Darmstadt), a highly purified water $\left(18 \mathrm{M} \Omega\right.$ at $\left.25^{\circ} \mathrm{C}\right)$, which was made of using Direct $\mathrm{Q}$ 3UV Millipore (Molsheim, France)).

Standard samples: Piperidinium 2-((5-(furan-2yl)-4-phenyl-4H-1,2,4-triazol-3-yl)thio)acetate (API), furan-2-carbohydrazide (impurity 1), 2-(furan-2-carbonyl)$\mathrm{N}$-phenylhydrazine-1-carbothioamide (impurity 2), 5-(furan-2-yl)-4-phenyl-2,4-dihydro-3H-1,2,4-triazole-3-thione (impurity 3).

Chromatography conditions:

- column was $\varnothing 4.6 \times 30 \mathrm{~mm}$, reverse phase $\mathrm{C} 18,1.8 \mu \mathrm{m}$;

- column temperature was $40^{\circ} \mathrm{C}$;

- mobile phase A was $\mathrm{H}_{2} \mathrm{O} / 0.1 \% \mathrm{HCOOH}$;

- mobile phase $\mathrm{B}$ was $\mathrm{CH}_{3} \mathrm{CN} / 0.1 \% \mathrm{HCOOH}$;

- mobile phase flow rate was $400 \mu \mathrm{L} / \mathrm{min}$;

- isocratic elution was mobile phase $\mathrm{A} /$ mobile phase B (70:30);

- sample volume was $2 \mu \mathrm{L}$;

- diode-array detector ( $\lambda=276 \mathrm{~nm}$ (API), $256 \mathrm{~nm}$ (impurity 1), $258 \mathrm{~nm}$ (impurity 2), $258 \mathrm{~nm}$ (impurity 3));

Preparation of the mobile phase $A .1 .00 \mathrm{~mL}$ methanoate acid was diluted to $1000.0 \mathrm{~mL}$ with water.

Preparation of the mobile phase $B .1 .00 \mathrm{~mL}$ methanoate acid was diluted to $1000.0 \mathrm{~mL}$ with acetonitrile.

Preparation of the reference solution. $100 \mathrm{mg}$ (accurate weight) of piperidinium 2-((5-(furan-2-yl)-4-phenyl-4H-1,2,4triazol-3-yl)thio)acetate (standard sample) was dissolved in the water and was diluted to $100.0 \mathrm{~mL}$ with water. It was mixed.

Preparation of the test solution. $10.00 \mathrm{~mL}$ of the solution sample to be examined was diluted to $100.0 \mathrm{~mL}$.

Preparation of the solution for the chromatographic system suitability. $5 \mathrm{mg}$ of each impurity standard sample was dissolved in the solvent mixture (water/acetonitrile was 70:30) and was diluted to $100.0 \mathrm{~mL}$ with the solvent mixture. It was mixed (solution IA). $50 \mathrm{mg}$ of standard sample of API was dissolved in the solvent mixture (water/acetonitrile was 70:30). $1.00 \mathrm{~mL}$ of solution IA was added and it was diluted to $100.0 \mathrm{~mL}$ with the solvent mixture. It was mixed (solution IB).

ASSAY. Liquid chromatography conditions were described above. Reference solution was injected $n$ times. RSD was calculated by API peak. Injection was stopped when $\mathrm{RSD} \leq \mathrm{RSD}_{\text {max }}$ for content bias $5 \%$ (requirements of Ph. Eur. 2.2.46 and Ph. Ukr. 2.2.29 to RSD \% ${ }_{\text {max }}$, supplement 2 [3]). 
The solution of standard sample and test solution were injected alternately set number of times (n). The results were used in following calculations average. The percentage content of piperidinium 2-((5-(furan-2-yl)-4-phenyl-4H-1,2,4triazol-3-yl)thio)acetate was calculated from the declared content of chemical reference substance. The retention time of API peak was about 2.7 minutes.

Preparation of the API model solutions for method validation. $1 \%$ solution of API was prepared (isotonic by addition $0.55 \mathrm{~g}$ of sodium chloride to $100 \mathrm{~mL}$ ).

$8.00,8.50,9.00,9.50,10.00,10.50,11.00,11.50,12.00$ $\mathrm{mL}$ of it solution were diluted to $100.0 \mathrm{~mL}$.

\section{Results and discussion}

Substantiation method conditions

Hydrazide, carbothioamide and thion are possible impurities which are intermediates in the API synthesis [4].

Optimization of the acetonitrile concentration in the mobile phase

Previously stationary and mobile phase have been selected. Chromatographic behavior of 1,2,4-triazoles derivatives and intermediates in their synthesis was studied [5-7].

These patterns were used for graph construction of the capacity factor from the acetonitrile concentration dependence in the mobile phase for potential impurities and API on diode-array detector wavelength $254 \mathrm{~nm}$ (Fig. 1).

On the chart we can see that the maximum difference between the lines is about $30 \%$ with the minimal capacity factor, i. e. the minimal retention time and minimal analysis time. Resolution $\left(R_{s}\right)$ can be used to characterize the quality of separation. Experimental determination and calculation of the resolution $\left(R_{s}\right)$ were conducted according to the $P h$. Eur. 2.2.46 and Ph. Ukr. 2.2.29 using the OpenLAB CDS Software $[8,9] . R_{s} \geq 4.1$ (between API peak and compound peak (3)) and $R_{s} \geq 2.7$ (between compound (4) and API peaks (1)). The separation between API peak (1) and carbothioamide (3), API peak (1) and thion (4) peaks are satisfactory, because conforming Ph. Ukr. 2.2.29 (have to be $\geq 1$ ) [8].

A chromatogram of reference solution (a solution of a standard sample substance piperidinium 2-((5-(furan-2-yl)-4phenyl-4H-1,2,4-triazol-3-yl)thio)acetate) is shown in Fig. 2.

The selecting of analytical wavelength for quantification of the API was based on the UV spectrum study (Fig. 3). The absorption spectrum was measured in the cell of diode-array detector with substance elution by $30 \%$ acetonitrile containing $0.1 \%$ methanoate acid.

API peak purity was verified by mass spectrometric detector (Fig. 4). Peak purity report according to the mass spectrometric detector presented that: "The analysis found only one component, indicating a pure peak. Component 1 : Peak at Scan 290.1. Top ions are 302, 303"

The method uncertainty prediction. Calculation of uncertainty the solution standard sample (reference solution) preparation:

- weighing standard sample of API: $(0.1 \mathrm{mg} / 100 \mathrm{mg})$ $\times 100=0.1 \%$;

- dilution of the solution in a volumetric flask $100.0 \mathrm{~mL}$ : $0.12 \%$.

Calculation of uncertainty of the test solution preparation:

- measuring of the volume of $1 \%$ test solution of API $10.00 \mathrm{~mL}: 0.5 \%$;

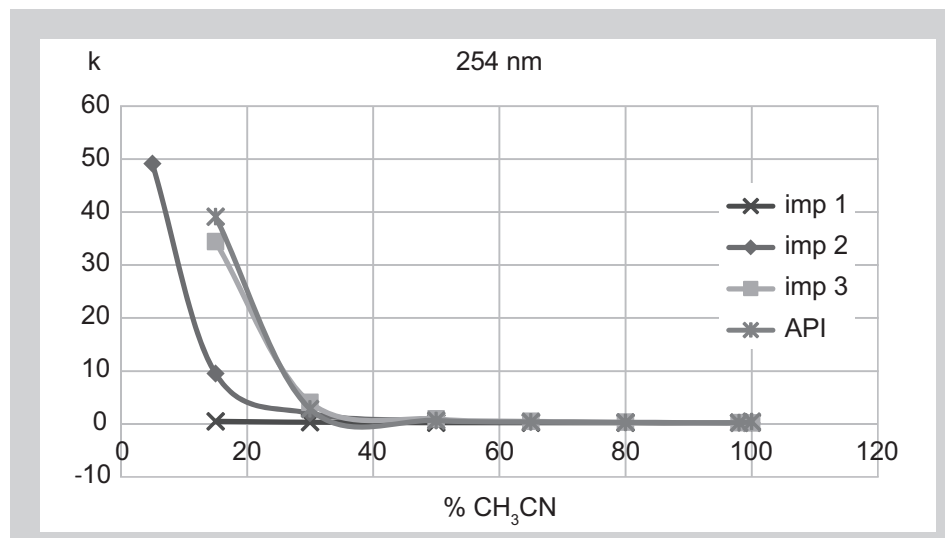

Fig.1. Dependence of the capacity ( $k$ ) from the concentration of acetonitrile in the mobile phase.

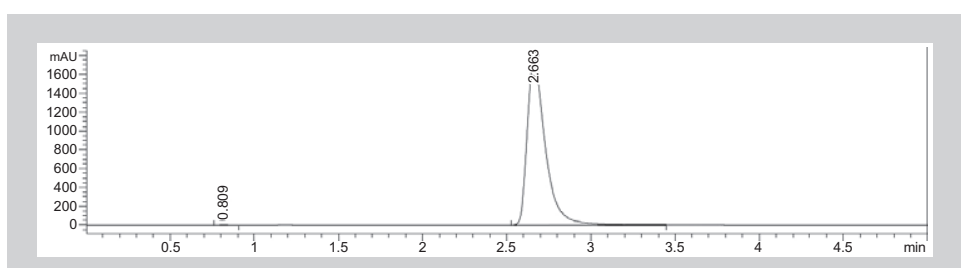

Fig. 2. A chromatogram of API reference solution $276 \mathrm{~nm}$.

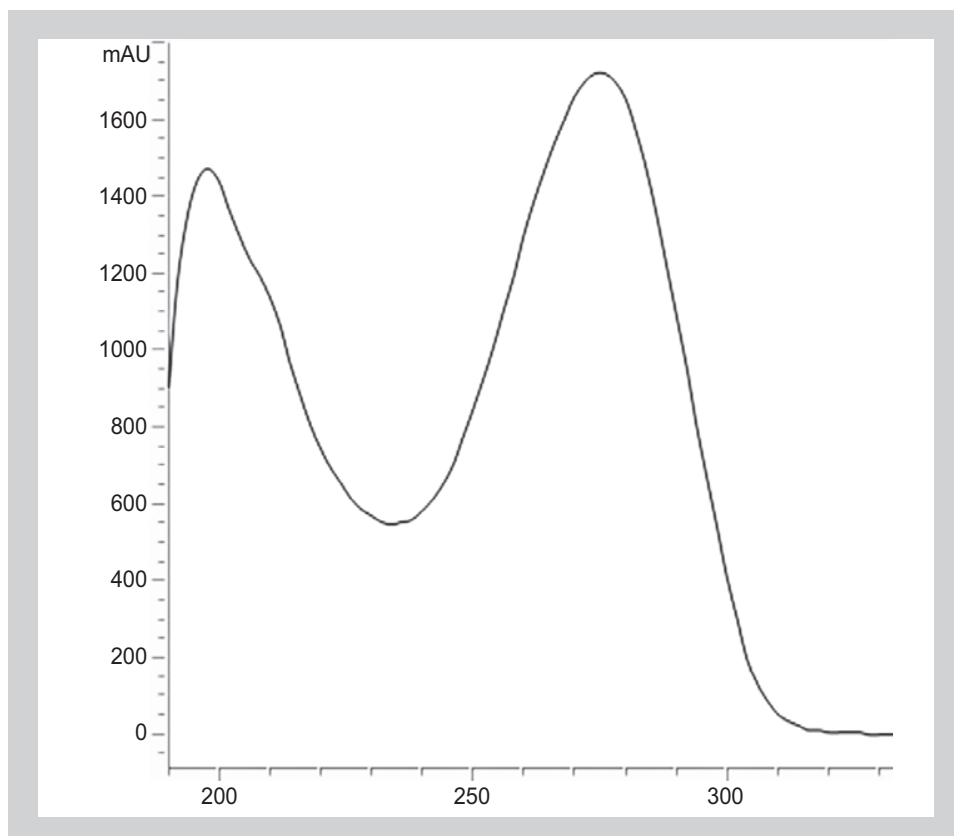

Fig. 3. The absorption spectrum of API.

- dilution of the solution in a volumetric flask $100.0 \mathrm{~mL}$ :

$0.12 \%$.

$$
\begin{gathered}
\Delta_{S P}=\sqrt{0.1^{2}+0.12^{2}+0.5^{2}+0.12^{2}}= \\
=\sqrt{0.01+0.0144+0.25+0.0144}=0.537 \%
\end{gathered}
$$

According to the Ph. Ukr. (supplement 1 and 2) uncertainty of sample preparation should be insignificant compared with a maximum uncertainty analysis techniques, i. e. $\Delta_{\mathrm{SP}} \leq 0.32 \Delta_{\mathrm{As}}=0.32 \times 0.32 \times 5=0.521 \%[3,10]$. 

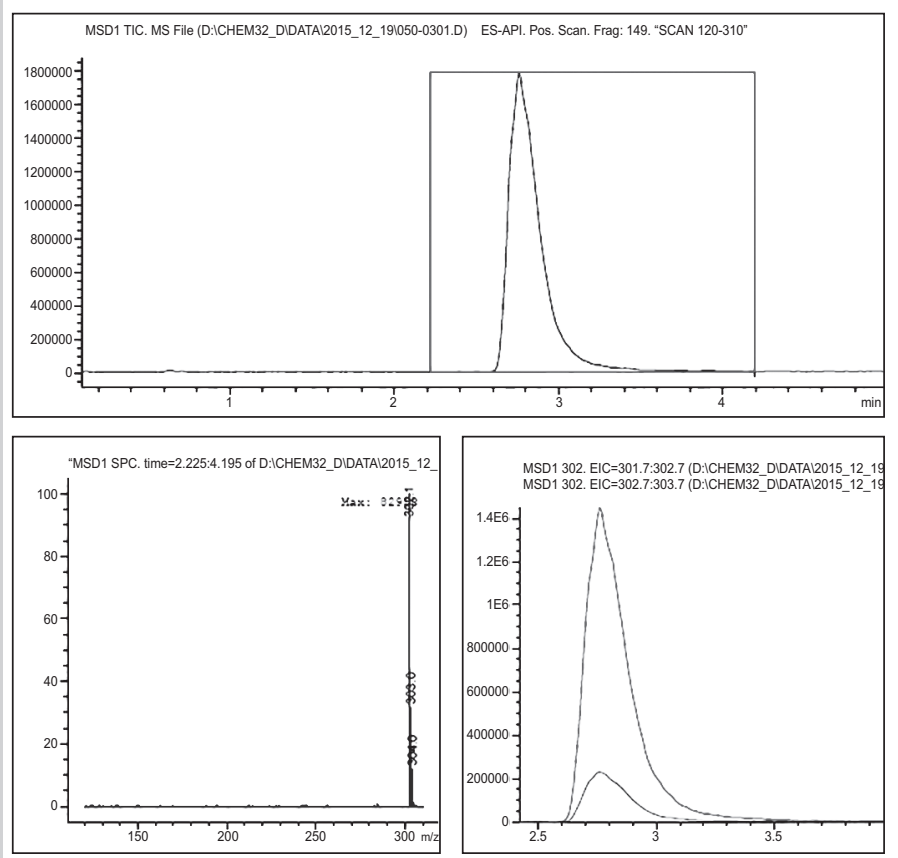

Fig. 4. API peak purity by mass spectrometric detector

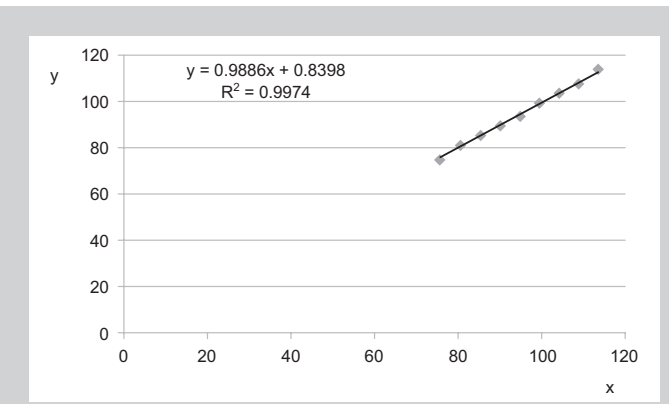

Fig. 5. Linear dependence of the API peak area from concentration in the normalized coordinates.

Table 1. Metrological characteristics of linear dependence for the quantitative determination method of API in $1 \%$ injection solution $Y=b X+a$

\begin{tabular}{llll}
\hline Parameter & Value & $\begin{array}{l}\text { Criteria of acceptability } \\
(B=5 \%, g=9)\end{array}$ & Conclusion \\
\hline$b$ & 0.9886 & - & - \\
$S_{b}$ & 0.01891 & - & - \\
$a$ & 0.8398 & $\leq 2.6$ & complied \\
$s_{a}$ & 1.803 & - & - \\
$R S D_{0}$ & 0.6926 & $\leq 0.84$ & complied \\
$R_{c}$ & 0.9987 & $\geq 0.9981$ & complied \\
\hline
\end{tabular}

Table 2. The results of precision and accuracy estimation of the API quantitative determination method in the $1 \%$ injection solution

\begin{tabular}{|c|c|c|c|c|c|c|}
\hline Model solution & $\begin{array}{l}\text { Volume } 1 \% \mathrm{API} \text { model } \\
\text { solution, } \mathrm{mL} \\
\left(c_{\mathrm{st}}=0.10606 \mathrm{~g} / 100 \mathrm{~mL}\right)\end{array}$ & $\begin{array}{l}\text { Spiked API weight } \\
\text { in injected solution, } \\
\mathrm{g} / \mathrm{mL}\end{array}$ & $\begin{array}{l}\text { Spiked in } \% \\
\text { to concentration } \\
\text { of reference solution, } X_{i}\end{array}$ & $\begin{array}{l}\text { Mean peak area, } S_{i} \\
\left(S_{s t}=13329\right)\end{array}$ & $\begin{array}{l}\text { Found in \% to peak area } \\
\text { of reference solution, } \\
Y_{i}\end{array}$ & $Z_{i}=\frac{Y_{i}}{X_{i}} \times 100 \%$ \\
\hline 1 & 8 & 0.0008 & 75.66 & 9999.4 & 75.02 & 99.15 \\
\hline 2 & 8.5 & 0.00085 & 80.39 & 10808.2 & 81.09 & 100.86 \\
\hline 3 & 9 & 0.0009 & 85.12 & 11418.6 & 85.67 & 100.64 \\
\hline 4 & 9.5 & 0.00095 & 89.85 & 11908.3 & 89.34 & 99.43 \\
\hline 5 & 10 & 0.001 & 94.58 & 12469.8 & 93.55 & 98.91 \\
\hline 6 & 10.5 & 0.00105 & 99.31 & 13254 & 99.44 & 100.13 \\
\hline 7 & 11 & 0.0011 & 104.04 & 13797.7 & 103.52 & 99.5 \\
\hline 8 & 11.5 & 0.00115 & 108.77 & 14352.1 & 107.67 & 98.99 \\
\hline 9 & 12 & 0.0012 & 113.56 & 15162.4 & 113.75 & 100.2 \\
\hline \multicolumn{6}{|c|}{ The relative standard deviation, $R S D_{Z}, \%$} & 0.7261 \\
\hline \multicolumn{6}{|c|}{ The relative confidence interval, $\Delta_{z}=R S D_{z} \times t(95 \% ; \mathrm{n}-1)=R S D_{z} \times 1.8595$} & 1.350 \\
\hline \multicolumn{6}{|c|}{ The criterion of acceptability for convergence results: $\Delta_{\mathrm{As}} \leq 0.32 \times 5.00=1.6$} & complied \\
\hline \multicolumn{6}{|c|}{ Systematic error, $\delta=|100-\bar{Z}|$} & 0.2382 \\
\hline \multicolumn{6}{|c|}{$\begin{array}{l}\text { The criteria of insignificance of systematic error: } \\
\text { 1) } \delta \leq \Delta_{z} / 3=1.35 / 3=0.45 \\
\text { 2) } \delta \leq 0.32 \times \cdot 5=1.6\end{array}$} & complied complied \\
\hline \multicolumn{6}{|c|}{ The overall conclusion of the method } & correct \\
\hline
\end{tabular}

Table 3. Results of chromatography system suitability test for RSD

\begin{tabular}{lllll}
\hline Injection & $\mathbf{S}_{\mathrm{st}}$ & Mean value $\mathrm{S}_{\text {st }}$ & RSD $\%$ & RSD ${ }_{\text {max }}$ \\
\hline 1 & 13480.8 & - & - & - \\
2 & 13488.6 & 13484.7 & 0.04090 & 0.25 \\
3 & 13477.7 & 13482.4 & 0.04166 & 0.67 \\
4 & 13478.9 & 13481.5 & 0.03636 & 0.96 \\
5 & 13472.5 & 13479.7 & 0.03636 & 1.19 \\
\hline
\end{tabular}

Thus, the predicted value $\Delta_{\mathrm{SP}}$ did not meet Ph. Ukr. $(0.537 \%>0.51 \%)$. Therefore final analytical operation should be treated more stringent requirements.

$$
\begin{gathered}
\Delta_{A S}=0.32 \times B=0.32 \times 5=1.6 \%, \\
\Delta_{A S}=\sqrt{\Delta_{S P}^{2}+\Delta^{2}{ }_{F A O}}, \\
\Delta_{F A O}=\sqrt{\Delta_{A S}^{2}-\Delta_{S P}^{2}}=\sqrt{1.6^{2}-0.537^{2}}=\sqrt{2.65-0.288}=1.54 \%
\end{gathered}
$$


Table 4. The results of the quantitative determination API in the $1 \%$ injection solution

\begin{tabular}{|c|c|c|c|c|c|}
\hline Sample & $\begin{array}{l}\text { Sample volume (weight), } \mathrm{mL} \\
\text { (gram) }\end{array}$ & Peak area & Peak area average & Found API in \% & $\begin{array}{l}\text { Metrological characteristics, } \\
n-1=5, P=0.95\end{array}$ \\
\hline 1 & 10.00 & $\begin{array}{l}12319.7 \\
12290.9\end{array}$ & 12305.3 & 0.9678 & $\begin{array}{l}\bar{X}=09733 \\
S=0.01343 \\
S \underline{r}=1.380\end{array}$ \\
\hline 2 & 10.00 & $\begin{array}{l}12258.8 \\
12206.6\end{array}$ & 12232.7 & 0.9621 & $\begin{array}{l}\Delta \bar{X}=0.01409 \\
\varepsilon=1.448 \%\end{array}$ \\
\hline 3 & 10.00 & $\begin{array}{l}13544.9 \\
13600.2\end{array}$ & 13572.5 & 0.9669 & \\
\hline 4 & 10.00 & $\begin{array}{l}12273.3 \\
12296\end{array}$ & 12284.6 & 0.9662 & \\
\hline 5 & 10.00 & $\begin{array}{l}12414.1 \\
12444\end{array}$ & 12429.1 & 0.9785 & \\
\hline 6 & 10.00 & $\begin{array}{l}12724.3 \\
12662.6\end{array}$ & 12693.5 & 0.9984 & \\
\hline Reference solution & 0.1061 & 13484.7 & & & \\
\hline
\end{tabular}

Validation characteristics of a method

Validation of the method was performed according to the requirements of $\mathrm{Ph}$. Ukr. in the standard method version by the standardized procedure $[3,10,11]$. API content bias of $1 \%$ injection solution is $5 \%$.

Linearity. Linear dependence graph in normalized coordinates, an equation of calibration graph and $R^{2}$ value is presented at the Fig. 5. Metrological characteristics of linear dependence for the method application range $80-120 \%$ for nominal API content is presented in the Table 1. Method is linear at entire range and meets $\mathrm{Ph}$. Ukr. [3,10].

Specificity. PeakAPI completely separated from impurities peaks $1,2,3$. Resolution is $R_{s} \geq 4.1$ (between $A P I$ and impurity 2 peaks) and $R_{s} \geq 2.7$ (between impurity 3 and API peaks).

Precision and accuracy. Results of the precision and accuracy estimation of the API quantitative determination method are presented in the Table 2. The results show that the method meets the requirements of $\mathrm{Ph}$. Ukr. to precision and accuracy $[3,10]$.

Applying the developed method to quantify API in the $1 \%$ injection solution

$10.00 \mathrm{~mL}$ of test solution into 6 flasks was poured. It was diluted to $100.0 \mathrm{~mL}$.

Reference solution was injected $\mathrm{n}$ times for determination of RSD. A number of the repeat injections ware determined according to the requirements for Ph. Eur. 2.2.46 and Ph. Ukr. 2.2.29 to RSD \%.

Each solution measured by pipet obtained from 6 samples was injected.

An analysis of prepared solutions for content of piperidinium 2-((5-(furan-2-yl)-4-phenyl-4H-1,2,4-triazol-3-yl)thio) acetate was conducted.

Reference solution injection was done 5 times. Results are shown in Table 3. The resulting value did not exceed RSD requiments Ph. Ukr. 2.2.29 to RSD $\%_{\text {max }}$ with all values of $n$, starting with $n=2$. So it was enough 2 times alternate injectons reference solution and test solution for each solution sample [3].

The results of API determination in the real solutions (Table 4) was reprodusible. The method may be usable to determine API in the samples of $1 \%$ solution for injection in their manufacture and storage.

\section{Conclusions}

1. The chromatography separation conditions of impurities and Piperidinium 2-((5-(furan-2-yl)-4-phenyl-4H-1,2,4triazol-3-yl)thio)acetate were studied.

2. The method of determination of Piperidinium 2-((5-(furan-2-yl)-4-phenyl-4H-1,2,4-triazol-3-yl)thio)acetate in $1 \%$ solution for injection was elaborated.

3. The results of the method validation show that it is specific and meet the requirements of linearity, precision and accuracy.

4. The results of API content determination in real samples of solutions for injection indicate that the method can be proposed for quality control of $1 \%$ solutions for injection.

\section{Acknowledgements}

We acknowledge complete support of the Zaporizhzhia State Medical University. We thank rector of Zaporizhzhia State Medical University Prof. Yu. M. Kolesnyk for his help and support.

\section{References}

[1] Parchenko, V. V., Panasenko, O. I., Knysh, E. G., Vasiuk, S. O., \& Tarkhanova, O. O. (2009). Yakisne ta kilkisne vyznachennia piperydynii 2-[5-(furan-2-il)-4-fenil-1, 2, 4-tryazol-3-iltio] atsetatu 1\% ta 2,5\% rozchynakh [Qualitative and quantitative determination of the Piperidinium 2-((5-(furan-2-yl)-4-phenyl-4H-1,2,4-triazol-3-yl)thio)acetate $1 \%$ and $2,5 \%$ solutions]. Zaporozhye medical journal, 3, 111-112. [in Ukrainian].

[2] Parchenko, V. V., Panasenko, O. I., Knysh, E. G., Vasyuk S. O., \& Tarkhanova, O. O. (2009). Rozrobka metodyky kilkisnoho vyznachennia piperydyniiu 2-[5-(furan-2-il)-4-fenil-1,2,4- tryazol-3-iltio] atsetatu v substantsii [Working out of methods quantitative determination piperidiniy 2-[5-(furan-2-il)-4-phenil-1,2,4-triazol-3-ilthio]acetate in the substance]. Ukrainskyi biofarmatsevtychnyi zhurnal, 4, 44-45. [in Ukrainian].

[3] (2008) Derzhavna Farmakopeia Ukrainy. Dopovnennia 2. [The State Pharmacopoeia of Ukraine. Supplement 2]. Kharkiv: RIREH. [in Ukrainian].

[4] Parchenko, V. V. (2006). Syntez, fizyko-khimichni ta biolohichni vlastyvosti pokhidnykh 1,2,4-triazol-3-tionu, yaki mistyat' yadro furanu (Dis... kand. farm. nauk). [Synthesis, physicochemical and biological properties of derivatives of 1,2,4-triazoles-3-thione containing core furan. Dr. farm. sci. diss.]. Zaporizhzhia [in Ukrainian].

[5] Varynskyj, B. O. (2015) Doslidzhennia kharkterystyk utrymuvannia riadu hidrazydiv karbonovykh kyslot i hidrazynokabotioamidiv, vykhidnykh rechovyn pry syntezi substantsii dlia vyhotovlennia likarskykh zasobiv metodom VERKh-UF-ESI-MS [Study retention characteristics of series hydrazides of carboxylic acids and hydrazynocabothioamids, 
starting materials in the synthesis of bulk drugs for manufacturing of the pharmaceutical preparations by HPLC-UV-ESI-MS]. Problemy viiskovoi okhorony zdorovia. Zbirnyk naukovykh prats Ukrainskoi viys'kovo-medychnoi akademii, 43, 320-330. [in Ukrainian].

[6] Varynskyi, B. O., Knysh, Ye. G., Parchenko, V. V., Panasenko, O. I., \& Kaplaushenko, A. G. (2015) Vyvchennia zakonomirnostei utrymuvannia potentsiinykh likarskykh substantsii riadu 1,2,4-triazol-3-iltioatsetatnykh kyslot ta yikh solei metodom VERKh / DMD-MS [The study of retention regularities for the potential drug substances of 1,2,4-triazol-3-ylthioacetic acids and their salts series by the method of HPLC DAD-MS]. Zhurnal orhanichnoi ta farmatsevtychnoi khimii, 4, 68-72. [in Ukrainian].

[7] Varynskyi, B. O. (2016) Vyvchennia metodom VERKh-DMD-MS zakonomirnostei utrymuvannia riadu 1,2,4-triazol-3-tioniv - napivproduktiv v syntezi aktyvnykh farmatsevtychnykh inhrediientiv [Study by HPLCDAD-MS retention regularities of the 1,2,4-triazoles-3-tione series - intermediate materials in the synthesis of active pharmaceutical ingredients for medicine manufacture]. Farmakom, 1, 32-40. [in Ukrainian].

[8] (2001) Derzhavna Farmakopeia Ukrainy [The State Pharmacopoeia of Ukraine]. Kharkiv: RIREH. [in Ukrainian].

[9] (2013). European Pharmacopoeia. Strasbourg, France: Council of Europe.

[10] (2004). Derzhavna Farmakopeia Ukrainy. Dopovnennia 1. [The State Pharmacopoeia of Ukraine. Supplement 1]. Kharkiv: RIREH. [in Ukrainian].

[11] Grizodub, A. I. (2011) Standartizovannye procedury validacii metodik kontrolya kachestva lekarstvennykh sredstv [Standardized validation procedures for method of medicines quality control]. Analiticheskaya khimiya v sozdanii, standartizacii y kontrole kachestva lekarstvennykh sredstv, V. P. Georgievskogo (Ed.), (Vol. 3). Kharkiv, pp. 934-1063. [in Russian].

\section{Information about authors:}

Varynskyi B. O., Ph.D., Associate Professor, The Department of Physical and Colloidal Chemistry, Zaporizhzhia State Medical University, Ukraine.

Parchenko V. V., Dr.hab., Professor, The Department of Toxicological and Inorganic Chemistry, Zaporizhzhia State Medical University, Ukraine.

Kaplaushenko A. G., Dr.hab., Associate Professor, Head of The Department of Physical and Colloidal Chemistry, Zaporizhzhia State Medical University, Ukraine.

\section{Відомості про авторів:}

Варинський Б. О., канА. фарм. наук, Аоцент каф. фізколоїАної хімії, Запорізький державний медичний університет, Україна. Парченко В. В., А-р фарм. наук, професор каф. токсикологічної та неорганічної хімії, Запорізький державний медичний університет, Україна.

Каплаушенко А. Г., А-р фарм. наук, Аоцент, зав. каф. фізколоїАної хімії, Запорізький Аержавний медичний університет, Україна.

\section{Сведения об авторах:}

Варинский Б. А., канА. фарм. наук, Аоцент каф. физкоммоидной химии, Запорожский государственный медицинский университет, Украина.

Парченко В. В., А-р фарм. наук, профессор каф. токсикологической и неорганической химии, Запорожский государственный медицинский университет, Украина. Каплаушенко А. Г., А-р фарм. наук, Аоцент, зав. каф. физкомлоиАной химии, Запорожский государственный медицинский университет, Украина.

Конфмікт інтересів: віАсутній.

Conflicts of Interest: authors have no conflict of interest to declare.

Навійшло Ао реАакції / Received: 13.06.2017

Після Аоопрацювання / Revised: 01.09.2017

Прийнято Ао Аруку / Accepted: 13.09.2017 